denne artikkelen har fått kritiske anmerkninger med henblikk på pasientutvalg og analysemetoder (2). En annen artikkel viser en tvilsom økning i infeksiøse komplikasjoner ved kolektomi, men forfatterne påpeker at immunhemmende kombinasjonsbehandling var årsaken (3). Prednisolonbruk og alvorlighetsgrad av sykdommen er også signifikante faktorer for økt postoperativ infeksjonsrisiko (4).

Vi konkluderer med at det er uklart om infliximab øker faren for postoperative infeksiøse komplikasjoner ved ulcerøs kolitt og Crohns kolitt hos pasienter som blir akutt kolektomert. Derimot gir høye doser prednisolon alene eller i kombinasjon med andre immunhemmere før kolektomi $ø k t$ infeksjonsfare. Hos disse pasientene er det grunn til å vurdere nøye hvilken behandlingsstrategi man skal velge. Tett tverrfaglig samarbeid mellom gastromedisiner og gastrokirurg er en selvfølge hos disse alvorlig syke pasientene når operasjon kan bli et alternativ.

\section{Tom øresland}

Akershus universitetssykehus

Bjørn Moum

Oslo universitetssykehus, Aker

Litteratur

1. Mor IJ, Vogel JD, da Luz Moreira A et al. Infliximab in ulcerative colitis is associated with an increased risk of postoperative complications after restorative proctocolectomy. Dis Colon Rectum 2008; 51 : 1202-7; discussion 1207-10.

2. Bordeianou L. In flux on infliximab: conflicting studies on surgical outcomes. Inflamm Bowel Dis 2009; 15: 1605-6.

3. Selvasekar CR, Cima RR, Larson DW et al. Effect of infliximab onshort-term complications in patients undergoing operation for chronic ulcerative colitis. J Am Coll Surg 2007; 204: 956-62; discussion 962-3

4. Aberra FN, Lewis JD, Hass D et al.Corticosteroids and immunomodulators: postoperative infectious complication risk in inflammatory bowel disease patients. Gastroenterology 2003; 125: $320-7$.

\section{Om baker og smed, bukkene Bruse og havresekken}

Blåreseptnemnda har en rådgivende og kvalitetssikrende funksjon overfor Statens legemiddelverk (SLV) i forbindelse med søknader fra farmasøytisk industri om å få forhåndsgodkjent refusjon og opptak av legemidler i blåreseptordningen. Dette betyr ikke at Blåreseptnemnda tar stilling til alle spørsmål om refusjon; vi prøver å svare på de spørsmål Legemiddelverket stiller, og vi har ingen besluttende myndighet. Når Terland i Tidsskriftet nr. 12/ 2009 og nr. 18/2009 tillegger Blåreseptnemnda ansvaret for tiazid- og simvastatinvedtakene $(1,2)$, retter han baker for smed; Blåreseptnemnda ble ikke forespurt i de to sakene.

De overordnede faglige kriteriene for pliktmessig refusjon av legemiddelutgifter over blåreseptordningen utgjøres av følgende:

- Legemidlet skal brukes til behandling av alvorlige sykdommer eller av risikofaktorer som med høy sannsynlighet vil medføre eller forverre alvorlig sykdom

- Sykdommen eller risiko for sykdom som nevnt ovenfor medfører behov eller risiko for gjentatt behandling over en langvarig periode

- Legemidlet har en vitenskapelig godt dokumentert og klinisk relevant virkning $i$ en definert, aktuell pasientpopulasjon

- Kostnadene ved bruk av legemidlet står $i$ et rimelig forhold til den behandlingsmessige verdien og til kostnader forbundet med alternativ behandling

Alle disse fire kriteriene må være oppfylt. Ordningen administreres av Legemiddelverket, som altså rådgis av Blåreseptnemnda, og som i disse spørsmålene er i linje under hhv. Helse- og omsorgsdepartementet og Stortinget.

Terland skriver (2) at «det blir feil når det er den som betaler for legemidlene, som også setter opp reglene». Her er Terlands logikk ikke helt enkel å følge. Staten finansierer blåreseptordningen. Vel 8 milliarder kroner ble brukt på legemidler i 2008, og da er det som forventet - og en del av demokratiets spilleregler - at staten også må føre tilsyn med at pengene brukes i samsvar med intensjonene. Dette er i prinsippet ikke forskjellig fra den situasjonen som foreligger når Terland bærer sin egen pengepung rundt om i butikkene; han bestemmer selv hva han vil kjøpe! Det er heller ingen som vil frata Terland hans frie forskrivningsrett. Det besværlige «regelrytteriet» oppstår når han vil bruke andre penger enn egne eller pasientens.

Han skriver videre (2) at «en overvel- dende mengde litteratur ... tar livet av tiazid» som behandlingsalternativ, og karakteriserer bruk av simvastatin fremfor atorvastatin som nærmest rettsstridig. Han er selektiv i valget av litteraturreferanser, og han er i utakt med tunge, uavhengige fagmiljøer både i Norge og internasjonalt.

Terland uttrykker at han og hans kolleger er best i stand til å forvalte blåreseptordningens ressurser. Hvor velfundert er dette? Det finnes flere eksempler på at terapitradisjoner lettere kan forstås som produkter av industriens reklame enn som uttrykk for godt funderte, faglige vurderinger. Kan det tenkes at det på beitemarkene rundt havresekken også finnes flere andre, store og sterke bukker enn den statlige?

\section{Anne Elise Eggen}

Blåreseptnemnda

\section{Litteratur}

1. Terland 0 Regelrytteri i blåreseptordningen. Tidsskr Nor Legeforen 2009; 129: 1239.

2. Terland O. Bukken og havresekken. Tidsskr Nor Legeforen 2009; 129: 1900.

\section{RETTELSE}

1880 - 2005 - fra fattigdomssykdommer til overflodslidelser

Geir Stene-Larsen

Tidsskr Nor Lægeforen 2006; 126: 38-43

I figur 1, side 40, er det ukorrekt tidsangivelse på $\mathrm{x}$-aksen. Her er korrekt figur.

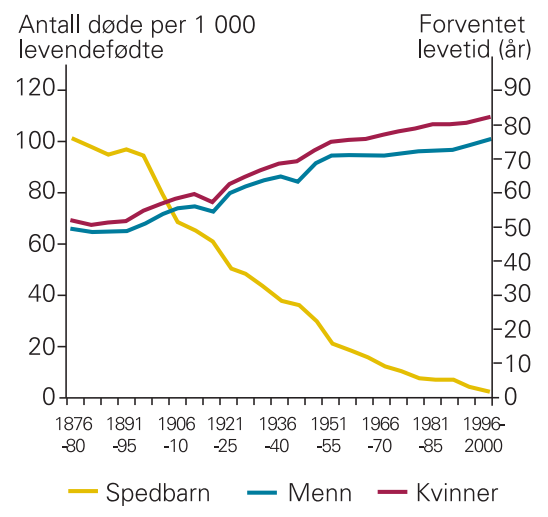

